\title{
CONFRONTING AMATEUR AND ACADEMIC AUDIODESCRIPTION: A BRAZILIAN CASE STUDY ${ }^{1}$
}

\author{
Eliana P. C. Franco, Sandra R. Rosa Farias, \\ Íris Fortunato e Manoela Cristina da Silva
}

\section{Introduction}

According to the 2000 census published by the Brazilian Institute of Geography and Statistics (IBGE), $14.5 \%$ of the Brazilian population have some kind of physical impairment. The largest percentage is found in the Northeast (16.8\%), and the smallest percentage is in the Southeast $(13.1 \%)$. As regards visually impaired people, in 2000 there were 148,000 blind people, and 2.4 million people who had considerable sight problems. Among the blind, 77,900 were women and 70,100 were men. In Brazil as a whole, the Northeast had the highest concentration of blind people - 57,400 - against 54,600 in the Southeast. São Paulo was the state in the Southeast with the largest concentration of blind people $(23,900)$, followed by the Northeastern state of Bahia, with 15,400 blind people. ${ }^{2}$ In 2004, according to the World Health Organization, there were 5 million blind people in Brazil (Revista $O$ Globo, 15 August 2004), and according to TV Câmera (30 March 2005), in 2005 there were 25 million people who were either blind or visually impaired.

For Hall (1986), sight is a sense whose importance goes beyond capturing information. It has a very specific informative role that can translate into interest, attraction or repulsion, permeating the types of relationships that can be established through it in society. The loss of sight (partial or total) compromises the bio-psychosocial participation of the individual because s/he will not be able to follow the normality pattern established by society (Santos, 2004). Ochaita \& Rosa (1988) claim that the blind individual represents the world in a qualitatively different way; that is, the blind person adapts to the sensorial information that is at his/her disposal. According to Martín \& Bueno, 2003), these individuals follow a development parallel to that of those

\footnotetext{
1 Esse trabalho foi apresentado em forma de comunicação em congresso internacional sobre audiodescrição na Universidade de Surrey, Inglaterra, em julho de 2007, pela Profa. Dra. Eliana P. C. Franco.

${ }^{2}$ These and other data were presented in Barcelona (2005) at the International Conference MEDIA FOR ALL and in Copenhagen (2006) at the International Conference MUTRA - Audiovisual Translation Scenarios, and published in Franco (2007).
} 
FRANCO ET AL. - Confronting Amateur and Academic Audiodescription...

who can see, but their organisms make use of other senses which, if properly stimulated, can compensate for the lack of sight, in such a way as not to impair their general development dramatically.

Therefore, tools should be offered to blind and visually impaired individuals in order to enable them to experience the widest variety of situations, allowing for the development of emotional, cognitive and psychomotor aspects. Verbal language in particular is a fundamental information tool for the visually impaired individual. It builds the bridge to the environment that surrounds this individual, especially when tactile contact is not an alternative.

In this context, audiodescription has been the most recent linguistic device used in the cinema, theatre and on television to help the blind and visually impaired to fully enjoy a film, play or programme. Defined as an intersemiotic mode of audiovisual transfer, it has been practiced in the United States and Japan since the 1980s, followed by many countries in Europe, such as the United Kingdom, Germany, France, Spain and recently Portugal. $^{3}$ In Europe, audiodescription has been taught in Audiovisual Translation courses and specific seminars, those promoted by UAB in Catalonia, and discussed at a number of conferences, as that in Surrey (June 2007) where this paper was presented.

In Brazil, the situation is different. Although supported by the Accessibility Law 10.098/2000, audiodescription became a reality on open television just from 1 July 2011 on, when channels were forced to broadcast two hours of audiodescribed programming per week, a very limited time compared to the daily two-hour programming that was firstly envisaged by the law. Until audiodescription became compulsory on open Brazilian TV, private initiatives in the theatre, film festivals and on DVD were solely responsible for promoting audiodescription in the country. Formal training and research was introduced in 2004 in very few academic institutions, most of them in the Northeast of Brazil, including the research group TRAMAD (Translation, Media e Audiodescription) $)^{4}$ formed by the authors of the present paper. Since 2005 the research group has studied users' reactions to audiodescribed products in order to elaborate an audiodescription model that can account for main preferences and serve as a guide to the training of audiodescribers. Now that the rules for audiodescription

\footnotetext{
${ }^{3}$ More about audiodescription in Europe can be found in Ballester Casado (2007).

${ }^{4}$ For additional information on the group, go to www.tramad.com.br.
} 
FRANCO ET AL. - Confronting Amateur and Academic Audiodescription...

practice are being written by ABNT, reception research has gained major importance, although some people from outside the academia involved in the process of formulating audiodescription practice instructions have unfortunately failed to recognize this fact.

Basic rules applied to the products audiodescribed in Brazil by the group TRAMAD were learned in workshops by specialists from Germany (Berlin, 2004 and Barcelona, 2006), the UK (Barcelona, 2005) and the United States (Portugal, 2006). These were tested with Brazilian groups of blind and visually impaired people from an institution in the city of Salvador (the Associação Baiana de Cegos) and two institutions in the city of São Paulo (Laramara and Dorina Nowill). One of these reception tests was documented in Franco (2007). Most of them consist of short films, produced in the state of Bahia and in the south of the Brazil, now also including a dance performance.

Starting from Dosch \& Benecke's "three golden rules" (2004) - do not anticipate, do not interpret and do not summarize - the group observed a number of local preferences. Indeed, the target audiences seemed to enjoy as much description as possible, including the explanation of certain items that might be unknown to them, depending on the topic of the audiovisual product and cultural differences. Because Brazil is a big country, regions have their own customs, ways of speaking, different expressions and vocabulary, which might not always be grasped by an audience from a different region. In addition, certain elements that may not be an issue in one region might be in another. For example, being from a predominantly white region, I was surprised when students - from a predominantly black region - questioned my description of the protagonist as a young black male. The fact that we live in a city where the majority of the population is black made my description of the protagonist's skin colour irrelevant in a short-film produced by a local of Bahia and aimed at the visually impaired audience of the city of Salvador. Accordingly, the Brazilian audiodescription model based on reception research respondents should include not only a detailed verbal description of the images, but also the explanation of cultural or specific items whenever necessary.

Taking advantage of the launching of the first audiodescribed DVD film in the market, the results obtained in academic research could then be confronted with a different audiodescription practice. Irmãos de Fé (2004), starred by the popular Father Marcelo, was audiodescribed by its DVD director, who had no experience or knowledge in the field of audiovisual translation, as he himself puts it in the making-of section of 
FRANCO ET AL. - Confronting Amateur and Academic Audiodescription...

the DVD. As a first step in the study, the research group observed certain audiodescription practices that did not take into account the preferences described by its previous reception studies, including the presence of many silences in between dialogues, the description of actions that were not conveyed visually, the lack of synchrony between audiodescription and background sounds, the lack of emphasis on the protagonist, the use of filmic terminology (e.g. flashback), to mention just a few. As the first audiodescribed audiovisual product that was put on the Brazilian market, this film had a great impact on the blind and visually impaired community. However, the research group aimed at providing this community with a means of comparison and at testing preferences previously observed. To this end, a reception study project was carried out with the aim of comparing a sequence of the commercial version of the film with an 'experimental' version of the same sequence, audiodescribed by the academic research group, who had previous knowledge of audiodescription and some of the main target audience's preferences.

The case study is presented as follows: Section 2 describes the steps followed by the academic group before and during the audiodescription of a sequence of the film Irmãos de Fé as well as the final audiodescription script that the group produced. Section 3 introduces the steps of the reception test conducted with the visually impaired audience and the results obtained. Finally, on the basis of the results, a few comments are made.

\section{Audiodescribing Irmãos de Fé (Brothers in Faith)}

In this section, the reader will be shown how the selection of the sequence to be audiodescribed by the academic group was made, the audiodescription process followed by the group and the main differences between the final audiodescription version written by the academic group and the audiodescribed version that was put on the market.

\subsection{The selection of the scene}

Irmãos de Fé is 105 minutes long. Due to the length of the film and to the fact that, for the purposes of comparison, the research subjects (a group of blind and visually impaired members of the Blind Association of Bahia - ABC) were supposed to watch, 
FRANCO ET AL. - Confronting Amateur and Academic Audiodescription...

on the same day, the amateur and the academic versions and to participate in an interview, the research group decided to work with a sequence instead of the entire film. It was necessary that the chosen sequence present a complete idea or episode, with beginning, middle and end, in order to get an idea of the whole film, which is extremely complex, with abrupt changes in time and space, since many stories are told simultaneously. The selected sequence, therefore, should also reflect this complexity, making it possible for spectators to grasp the cinematographic narrative of the original film and, for the researchers, to propose effective solutions for the many challenges found in a narrative of this nature.

The selected sequence is approximately 28 minutes long, beginning at minute 10.28 and ending at $37.53 \mathrm{~min}$. In this sequence, Paulo, a minor, is being kept at FEBEM - a state foundation that functioned as a detention centre for underage juvenile criminals - for having participated in the armed robbery of a couple at their front door. Father Marcelo visits him, but he is not welcomed by the boy. Before leaving, the priest gives Paulo a copy of the Bible with the aim of encouraging him to read "stories of love and courage." He tells Paulo about the story of a man with the same name as he. As soon as the priest leaves the room, Paulo throws the Bible at the door. The Bible falls open at Acts of the Apostles, exactly at the beginning of the story of the apostle Paul. After a while, having nothing to do, the bored youth starts reading the story. At this point the viewer is transported to Jerusalem soon after Christ's death, when Christians were persecuted by the Jews.

The boy's reading starts at the death of the apostle Stephen, planned and carried out by Saul, a jealous Jew infamous for persecuting Christians. In other words, two parallel scenes are presented simultaneously through the use of filmic editing devices, in particular cutting. On the one hand, the viewer sees Paulo, the boy, reading the Bible, and on the other hand, the viewer also follows the story of the evil Saul until his conversion - after he had a vision of Christ in the desert, which led him to temporary blindness - and baptism, when his name became Paul. The biblical narrative is repeatedly interrupted so that the story of the boy Paulo can continue, and the impact of Bible reading on him can be noticed visually.

According to the description of this sequence, one can imagine the difficulty for a blind audience to grasp not only the transitions in space and time, but also the great 
FRANCO ET AL. - Confronting Amateur and Academic Audiodescription...

amount of information that is encoded through images, especially in the second part of the scene, when the priest leaves the boy with the Bible and where there is no dialogue.

\subsection{The audiodescription process}

After selecting the sequence to be audiodescribed, the members of the research group worked individually to produce first draft versions of the audiodescription script. The researchers tried to elaborate the script with the least possible interference of the marketed version, with the aim of putting into practice their own knowledge of audiodescription. In the next stage, the different drafts were compared and merged for the elaboration of the final audiodescription script, also taking into account the available time between dialogues where the audiodescription would be recorded and mixed with the original soundtrack. ${ }^{5}$

The next stage was the recording of the script, made with the aid of the video editing program Pinnacle Systems. The entire audiodescription script was recorded in one go by one of the researchers who had already had some experience in live film narration and who had also recorded the first short film audiodescribed by the research group. After recording, the audiodescription track was edited and mixed with the original audio track of the film. Finally, DVD copies were made to be used during the reception test.

\subsection{The $\operatorname{product}(s)$}

As in any other translation process, the same source-text may give rise to as many audiodescriptions as the number of translators/audiodescribers. The selected sequence in question resulted in two very different versions - the amateur version, which was already available on the market, and the academic version.

In general, the academic version was characterised by a higher density of information. The descriptions of costumes, colours, characters' appearances and locations were as detailed as possible. The excerpts below, which are English translations of the Brazilian Portuguese script, illustrate some basic differences between the marketed or amateur version (MKV) and the academic version (ACV). The full text of the two Brazilian versions is presented in Appendix A.

\footnotetext{
${ }^{5}$ Although acknowledging its importance, the group did not rely on any blind or visually impaired informant when elaborating the final script. Consultancy with the blind people took place at a later stage.
}

Tradução em Revista 11, 2011/2, p. 6 
FRANCO ET AL. - Confronting Amateur and Academic Audiodescription...

One frequently observed difference is that the marketed version is often rather vague and simplified where the academic version was more precise and detailed. This can be observed in the examples below:

Example 1:

10:40 After the priest leaves, Paulo, the boy, throws the book on the wall. (MKV)

10:32 Paulo, a boy with straight, shoulder-length hair, wearing green pants and a red T-shirt, throws the Bible left by the priest on the wall. The Bible falls open at Acts of the Apostles. (ACV)

Example 2:

33:13 Sara tries to help him, but Saulo refuses her help. (MKV)

33:00 Sara approaches Saulo carrying water and a piece of cloth. She pours the water onto the cloth and moves it to the face of Saulo, who grabs her hand, refusing her help. Judas enters the bedroom. Some men are observing from the outside. (ACV)

Furthermore, the academic version also tried to avoid, as much as possible, incongruencies between audiodescription and images, mostly because there was enough space in the film for rich audiodescription. The marketed version included several instances where the audiodescription does not fully correspond to what is going on visually. In the following scene, for example, the boy does not turn to one side and then the other, and does not read the Bible sitting on the bed, but rather on the floor:

\section{Marketed version $(M K V)$ :}

11:02 The boy tries to sleep, turns to one side and then to the other, but cannot. 12:02 Then, he picks up the Bible off the floor, goes to bed and begins to read, trying to imagine the story.

\section{Academic version (ACV):}

10:54 The boy walks from one side of the room to the other, leans against the wall, puts his hand on the head, lies on his back on one of the beds, stands up and sits down on the floor.

11:12 The Bible is in front of him. The boy stretches his arm and grabs it, turns the pages, closes the Bible and throws it onto one of the beds. 11:30 He lies on the bed, stares at the ceiling, stands up and sits down on another bed, looking at the Bible. He picks it up, sits down on the floor and starts to read it. (ACV) 
FRANCO ET AL. - Confronting Amateur and Academic Audiodescription...

This excerpt is also a good example of how both versions deal differently with the issue of objectivity. One of the 'golden rules' in audiodescription is to describe as objectively as possible what is seen so that the audience itself may draw conclusions, as happens with a sighted audience that interprets the visual clues of a film. Therefore, instead of saying that the boy cannot sleep, a detailed description of his movements was preferred in order to express his anxiety. ${ }^{6}$

Finally, the academic version also aimed at adding more precise information, by making use of and explaining terms and specific practices that were culture and timebound and might seem too distant from the audience's world (e.g. synagogue, Torah, papyrus roll, to bow as a sign of respect, and so on):

\section{3:51 Jerusalem Temple. Daytime. Saulo is alone. (MKV)}

23:40 Saulo is in a synagogue, prostrated on the floor in the middle of the room, in front of the table where the Torah, the sacred book of the Jews, lies. He looks up and looks down a number of times. Three of his men are standing around him, close to the corners of the room. They observe Saulo. $(\mathrm{ACV})$

Now let us examine their impact on the visually impaired audience.

\section{The reception test}

The design of the reception test was the next stage in the research. Participants watched the marketed version followed by the academic version, without knowing which version they were watching. After each session, the same list of questions was presented in order to assess the level of content comprehension provided by each version. ${ }^{7}$ Finally the participants were invited to express their preferences for one of the versions, and to justify their choices not only in terms of the content of each audiodescription (i.e. what was and what was not described, the level of detail), but also in reference to form (i.e. timing, voice, silent spaces).

\footnotetext{
${ }^{6}$ The level of ideal interpretation is still a controversial topic. The subjectivity of the audiodescriber is always present, even if objectivity is the aim.

${ }^{7}$ Since the academic version presented more information (detailed descriptions, explanations of cultural references, etc), it was hoped that the understanding of the film sequence would be facilitated as compared to the marketed version. Therefore, if the academic version had been presented before the marketed version, the interview could have been influenced by the former, and potential gaps by the latter could not have been easily detected. However, it is acknowledged that the exhibition of the marketed
} 
FRANCO ET AL. - Confronting Amateur and Academic Audiodescription...

\subsection{The participants}

The study was initially done with 28 inhabitants of the city of Salvador. The participants were congenitally blind, had become blind, or had poor sight. According to our initial survey, their age ranged from 20 to 55; 11 were female and 17 male. As regards their educational background, only three were attending university. Three participants also claimed that they had never watched television, whereas the great majority were used to watching TV and said that their favourite programmes were cartoons, the news, soap operas and films. As to their previous experience with audiodescription, 22 participants had already experienced live narration of a film or program by friends or relatives, while six had never experienced it. None of the participants knew what audiodescription was about, and all but one confirmed that they would welcome more autonomy to watch films and programmes.

After the initial survey on the profile of our respondents, three did not participate in the actual reception research, so that the comprehension test and subsequent interview were carried out with 25 respondents.

\subsection{The interview}

The interview consisted of two parts: content understanding questions and free questions on the audience's preferences. Questions were presented orally ${ }^{8}$ after each version. Answers were all recorded for later qualitative and quantitative analysis. The content comprehension test consisted of the following questions:

1. What does Paulo, the boy, look like?

2. Why does Paulo walk from one side of the room to the other?

3. What is the boy reading? What is the story about?

4. Where and in which period do the stories of Estêvão and Saulo take place?

5. What happens to Estêvão?

6. Who is the man that Macária attacks/grabs?

7. Why does Saulo order Estêvão to be stoned?

8. What happens to Paulo at FEBEM at lunchtime?

9. Why does the priest go to see Paulo after the fight?

10. Does Paulo tell the truth to the priest? What does he actually say?

version before the academic version might also have affected the results, because when answering the questions after the academic version, the interviewees had already watched the same sequence twice.

${ }^{8}$ The making of questions in Braille was discarded by the lack of time and by the fact that none of the researchers could read Braille. 
FRANCO ET AL. - Confronting Amateur and Academic Audiodescription...

11. What happens in the synagogue?

12. What is the Torah? Why does Saulo look up and down in front of the table?

13. What do Saulo and his men do when they leave the synagogue?

14. What happens to Saulo on the way to Damascus?

15. What happens to Saulo at Judas' house?

16. Who is the man talking to Saulo at Judas' house? What is he going to do?

17. How is Saulo baptized?

18. What does Saulo want to be called now?

The second part of the interview was introduced by "Which of the audiodescription versions do you prefer? Why?" followed by many other open-ended questions and comments.

The comprehension test was designed to check not only how much visual information each version provided in the excerpt in question, but also how much each version contributed to the general understanding. Therefore, some questions, such as the first and the seventeenth, tested the quality of visual descriptions in each version, while other questions, like the third and the seventh, aimed at checking the contribution of each version to the level of understanding of the story being told. It was assumed that the more detailed the audiodescription was (more relevant and complete information), the more accessible the scene would become and, therefore, the better it would be understood. Finally, other questions, like the eleventh and the twelfth, were supposed to test whether elements alien to the local culture were taken into account. It is worth pointing out that the presence of this type of element may constitute an additional obstacle for the understanding of audiovisual material. When taken into careful consideration, audiodescription may play an educational role as well, enriching the audience's vocabulary and its knowledge of other cultures.

\subsection{The results}

Table 1 summarizes the answers given by participants to the content comprehension questions after watching the marketed/amateur and the academic versions. Comments on answers will be given afterwards.

\begin{tabular}{|l|c|c|l|c|}
\hline Question & Amateur version & $\begin{array}{c}\text { No. of } \\
\text { respondents }\end{array}$ & Academic version & $\begin{array}{c}\text { No. of } \\
\text { respondents }\end{array}$ \\
\hline 1 & $\varnothing$ & 0 & $\begin{array}{l}\text { Long hair, green trousers, red T-shirt. Later his } \\
\text { hair is cut and he wears a blue uniform. }\end{array}$ & All \\
\hline 2 & He is anxious, & 8 & He is anxious, disgusted, does not know what to & 21 \\
\hline
\end{tabular}


FRANCO ET AL. - Confronting Amateur and Academic Audiodescription...

\begin{tabular}{|c|c|c|c|c|}
\hline & $\begin{array}{l}\text { disgusted by the } \\
\text { story. }\end{array}$ & & $\begin{array}{l}\text { do there. He throws the Bible onto the floor, he } \\
\text { cannot sleep, he starts reading the Bible. }\end{array}$ & \\
\hline 3 & The Bible, Estêvão & 4 & $\begin{array}{l}\text { The Bible. A very cruel soldier. Then God, } \\
\text { Jesus converts him, makes him a soldier of God. } \\
\text { To teach people, to call them to the church. }\end{array}$ & 16 \\
\hline 4 & After Christ & 6 & After Christ & 15 \\
\hline 5 & He dies & 12 & $\begin{array}{l}\text { He is killed, stoned and thrown from the top of a } \\
\text { cliff. }\end{array}$ & 18 \\
\hline 6 & $\varnothing$ & 0 & Saulo, who pushes her onto the ground. & 11 \\
\hline 7 & $\varnothing$ & 0 & Because he was Jesus' follower. & All \\
\hline 8 & $\begin{array}{l}\text { He fights with the } \\
\text { other boys }\end{array}$ & All & $\begin{array}{l}\text { The other boys sit beside Paulo and keep } \\
\text { annoying him. }\end{array}$ & 16 \\
\hline 9 & $\begin{array}{l}\text { His sister asks him } \\
\text { to. }\end{array}$ & 8 & Because his sister asks him to. & 14 \\
\hline 10 & $\begin{array}{l}\text { No. He speaks a lot } \\
\text { of nonsense. }\end{array}$ & 3 & $\begin{array}{l}\text { No. He lies, says that the Bible was stolen. He } \\
\text { speaks a lot of nonsense, swear words. }\end{array}$ & All \\
\hline 11 & $\varnothing$ & 0 & $\begin{array}{l}\text { Saulo prays and gets together with the other } \\
\text { men. He receives some papers. }\end{array}$ & All \\
\hline 12 & $\varnothing$ & 0 & $\begin{array}{l}\text { The sacred book of the Jews. He prays, asks for } \\
\text { permission. }\end{array}$ & 16 \\
\hline 13 & $\varnothing$ & 0 & $\begin{array}{l}\text { They go after other people, they persecute those } \\
\text { who believe in Jesus. }\end{array}$ & All \\
\hline 14 & $\begin{array}{l}\text { He sees a shining } \\
\text { light. He goes } \\
\text { blind. }\end{array}$ & 15 & $\begin{array}{l}\text { He sees a shining light, he goes blind. One of his } \\
\text { men falls on his knee. The men are astonished. }\end{array}$ & 15 \\
\hline 15 & $\begin{array}{l}\text { He remembers his } \\
\text { cruel actions. }\end{array}$ & 12 & $\begin{array}{l}\text { He remembers his cruel actions and regrets } \\
\text { them. }\end{array}$ & All \\
\hline 16 & $\begin{array}{l}\text { Ananias. To heal } \\
\text { and convert him. }\end{array}$ & All & $\begin{array}{l}\text { Ananias. To heal his wounds, to convert him, to } \\
\text { baptize him. }\end{array}$ & All \\
\hline 17 & To his regret. & 6 & Ananias pours water onto his head. & 13 \\
\hline 18 & Paulo & All & Paulo & All \\
\hline
\end{tabular}

Table 1. Answers given by the blind and visually impaired audience to the content comprehension questions

At first glance, one can notice that the academic version allowed all of the 18 questions $(100 \%)$ to be answered by the visually impaired audience, whereas the amateur/marketed version allowed 12 questions $(67 \%)$ to be answered. In other words, no questions were left unanswered by the visually impaired audience after watching the academic version, but, on the other hand, after watching the amateur/marketed version, six questions out of the 18 , or a third of the content comprehension questions, were left unanswered by the visually impaired audience. Considering the number of questions 
FRANCO ET AL. - Confronting Amateur and Academic Audiodescription...

that could be answered by all participants, we see that the academic audiodescription provided enough means for $32 \%$ of questions to be answered by all 25 participants, as opposed to only $12 \%$ of questions that could be answered by all participants based on the amateur/marketed audiodescription.

As regards the length of answers in Table 1, one can suppose that the academic version allowed more detailed and complete answers. However, getting the right content is the aim here. In order to assess an answer as correct or adequate or better, the research group decided to focus on additional information that would specify or refine the content of the answer given. So, let us compare answers given to both audiodescribed versions as transcribed in Table 1.

Questions 1, 6 and 12 could be answered by the audience only after having watched the academic version because this provided information that was not provided in the amateur/marketed audiodescription. Both answers to Question 2, based on the two audiodescribed versions, can be considered correct or adequate, although answers based on the academic version give more details of the situation. Answers to Question 3 , however, are different in the sense that those based on the academic version do explain what the story that the boy is reading is about, whereas "Saulo" does not really tell the story that the boy is reading. The same happens to Question 5, where answers based on the amateur version just say that "Estêvão dies" without saying how, as it is explained in answers based on the academic version ("He is killed, stoned and thrown from the top of a cliff'). Answers to Question 8, although correct, summarize the action at FEBEM when based on the amateur version and detail the action when based on the academic version. Answer to Question 10 based on the amateur version sounds incomplete when compared to answers based on the academic version, which add that, besides speaking a lot of nonsense, "the boy lies, says that the Bible was stolen." Answers to questions 15 and 16 based on both audiodescribed versions may be considered correct, although it is clear that the academic version allows extra details, such as "he regrets them" and "to baptize him." Answer to Question 17 as based on the amateur version is incorrect or inadequate because it does not answer how Saulo is baptized, as do answers based on the academic version.

It can be said that answers based on the academic audiodescribed version were more detailed and complete. It can also be assumed that the great majority of participants showed a better understanding of the film sequence through the 
FRANCO ET AL. - Confronting Amateur and Academic Audiodescription...

audiodescription version elaborated by the academic research group. However, it is true that, for some questions, the marketed/amateur version does provide enough information for participants to understand the film content. Yet, even in these cases, a few questions are left unanswered, such as questions 7, 11 and 13.

In terms of the informants' comments on preferences for audiodescription scripts, all the participants without exception favoured the academic version. They pointed to the importance of detailed information for the overall understanding of the film content and their mental construction of the story, for better characterization of the protagonist, as well as for a greater perception of the other culture by means of additional information or explanation. Some comments listed on Table 2 illustrate the preferences mentioned above.

\begin{tabular}{|l|}
\hline $\begin{array}{l}\text { “...and she talked, for example, about the Torah, which I didn't know and which I've learned about. In the other } \\
\text { version I didn't see these things." }\end{array}$ \\
\hline "The second [academic version], because it provides more information, it's more detailed." \\
"The second [academic version] it became easier, including the expression of feelings and emotions." \\
"I liked it because it told us what the boy was like and how he looks now, but I also wanted to know what Saulo \\
looked like, if he had a mean face, and the other characters, details that the first version [amateur] did not provide." \\
\hline "The second [academic version], because it provided more information, the scene was clearer, much more detailed. \\
\hline "'The second [academic version] let me visualize the story better than the first version [amateur]." \\
\hline $\begin{array}{l}\text { "The first [amateur version] did not provide many details, yet with the second version [academic] I could see the } \\
\text { story clearly." }\end{array}$ \\
\hline
\end{tabular}

Table 2. Comments by participants related to the preferred version

The above comments were selected to represent the main points raised by all participants when talking about their preferences. What emerges is that, in their view, audiodescription should consist of a description which provides as much detail as possible to help the audience visualize the story, the characters, their feelings and emotions, besides learning cultural information that is not necessarily presented visually.

However, it is necessary to be cautious when assessing comments because factors like the participants' diversified interests, social and cultural habits or different educational backgrounds may have an impact on the comprehension and appreciation of the chosen film. One of the interviewees, for example, said that she understood many things because she was an Evangelical and frequently read the Bible, which might have 
FRANCO ET AL. - Confronting Amateur and Academic Audiodescription...

led her to answer some of the questions on the basis of previous knowledge and not necessarily of the audiodescription presented during the reception test. As Farias (2005:79) points out,

The image that each individual constructs, more than a visual reference, is an active representation of his/her behaviour, formed by a group of small myths, rituals, taboos and positive and/or negative complexes, experiences, contact situations and the humanization process, besides the particularities of the groups and of the historical and cultural construction of the imaginary that motivate actions, interests and expectations. [authors' translation]

Another factor to be considered is the level of interest of each individual, as some watched the film more attentively than others, mainly because they either enjoyed cinema and/or had been more exposed to culture and art in general. As a consequence, these participants demonstrated more willingness to understand the whole research process in order to participate effectively.

Finally, it should be mentioned that, despite a clear preference for the academic version, participants did give some credit to the marketed/amateur version. Despite the poor description and the many blanks, participants affirmed that the marketed version would certainly be of great help if no other alternative were offered to the blind and visually impaired audience.

\section{Final comments}

The results obtained leave no doubt that audiodescription facilitates a better understanding of the audiovisual product. Nevertheless, as regards audiodescription models, the reception research presented in this paper demonstrates that the target audience is indispensable for establishing standards.

The comparison of two versions - the amateur/marketed and the academic - of the same film sequence, as tested with its target audience revealed the greater efficiency of the academic version regarding audience comprehension and pointed to a unanimous preference for the academic version, which differed from the amateur version in crucial aspects such as avoiding long silences, introducing characters from the beginning, describing the looks of characters and their emotions, detailing actions and locations and explaining cultural references that might remain obscure. In this sense, it may be said that preferences point once again to an audiodescription model that aims at completeness with an extra educational flavour.

Tradução em Revista 11, 2011/2, p. 14 
FRANCO ET AL. - Confronting Amateur and Academic Audiodescription...

Questions related to the narration of the audiodescription script - voice type and tone, recording quality and volume - have not been dealt with in this study. It is believed that each audiovisual product belongs to a different genre that has its own characteristics, and the narration should follow these characteristics as revealed by voice type, delivery style and mood. These undoubtedly have an impact on the final audiodescription script and should be considered in a later study.

As far as results and the preferred audiodescription model are concerned, these are limited to the group under study, the 25 blind and visually impaired interviewees from the city of Salvador, Bahia. Due to the huge contrasts found between the different regions of the country, mainly between the Northeast on one hand, and the Southeast and South on the other, the findings cannot be generalized. Therefore, the question that follows is what national or regional preferences or tendencies may be, as the reception test was carried out in the Northeastern state of Bahia. That is, would the Southeastern audience's preferences be similar to or different from those found out in this study? Intuition indicates that many other parts of the country have to be tested in order to arrive at any precise conclusion. Most important, though, is to ask whether audiodescription models as well as audiodescription norms, such as those being written by ABNT now, are of any use for such a diversified national audience and for such a great range of audiovisual genres.

\section{References}

BALLESTER CASADO, A. La audiodescriptión: apuntes sobre el estado de la cuestión y las perspectivas de investigación". In: FRANCO, Eliana P. C.; ARAÚJO V. Santiago (Orgs.) TradTerm, v. 13, p.151-169. 2007.

DOSCH, E. \& BENECKE, B. Wenn aus Bildern Worte Werden. Durch AudioDescription zum Hörfilm, München: Bayerischer Rundfunk, 2004.

FARIAS, S. R. R. Representação social de mulheres portadoras de cegueira congênita sobre sua deficiência: interferências no lazer. Feira de Santana, Bahia, 2005. Unpublished M.A. Thesis. Universidade Estadual de Feira de Santana.

FRANCO, E. P. C. Em busca de um modelo de acessibilidade audiovisual para cegos no Brasil: Um projeto piloto In: FRANCO, Eliana P. C.; ARAÚJO V. Santiago (Orgs.) TradTerm, p.171-185. 2007.

HALL, E. T. A dimensão oculta. Lisboa: Relógio D’Água Editores, 1986.

IBGE Censo 2000. Available at http://www.ibge.gov.br. 
FRANCO ET AL. - Confronting Amateur and Academic Audiodescription...

MARTÍN, M. B.; BUENO, S. T. Deficiência visual: aspectos psicoevolutivos e educativos. Translation by M. de L. Pedro. São Paulo: Santos, 2003.

OCHAITA, E.; ROSA, A. El niño ciego: percepción y desarrollo psicológico. In Alumnos con necesidades educativas especiales, Madrid: Popular, MEC, 1988.

SANTOS, A. Representação social do esporte sob a ótica de grupos de pessoas cegas. Salvador, Bahia, 2004. Unpublished Doctoral Dissertation. Faculdade de Educação, Universidade Federal da Bahia.

\section{Filmography}

MOACYR GÓES (dir.) Irmãos de Fé, Columbia Pictures, Brazil, 2004. 